\title{
Lumen
}

Selected Proceedings from the Canadian Society for Eighteenth-Century Studies

\section{Tous les Savoirs du Monde}

\section{James H. Marsh}

Volume 19, 2000

Material Productions \& Cultural Construction

Culture matérielle \& Constructions discursives

URI : https://id.erudit.org/iderudit/1012315ar

DOI : https://doi.org/10.7202/1012315ar

Aller au sommaire du numéro

\section{Éditeur(s)}

Canadian Society for Eighteenth-Century Studies / Société canadienne d'étude du dix-huitième siècle

\section{ISSN}

1209-3696 (imprimé)

1927-8284 (numérique)

Découvrir la revue

Citer cet article

Marsh, J. H. (2000). Tous les Savoirs du Monde. Lumen, 19, 55-67. https://doi.org/10.7202/1012315ar

Copyright (c) Canadian Society for Eighteenth-Century Studies / Sociéte canadienne d'étude du dix-huitième siècle, 2000
Ce document est protégé par la loi sur le droit d'auteur. L'utilisation des services d'Érudit (y compris la reproduction) est assujettie à sa politique d'utilisation que vous pouvez consulter en ligne.

https://apropos.erudit.org/fr/usagers/politique-dutilisation/ 


\section{Tous les Savoirs du Monde}

\section{What's in a Name?}

Even a casual user of the great reference works is bewitched by the very word, encyclopedia. The name speaks for the thing, or at least thus goes the tradition. Etymology declares that an encyclopedia makes a tour around the circle of knowledge, or, more exactly, of education. This ambitious word actually begins with a fault, for the word as it is was never a Greek word, but a mistranslation of two words, enkuklios paideia. It is not a matter of indifference that knowledge be represented as a circle, or by 'cycles,' for it implies the possibility of complete knowledge, of knowledge enclosed.

The image of a circle has still further interest; it supposes a centre, a set of parts that orbit around a common point. The notion of an encyclopedia has an objective air but, implicitly, it is a subjective notion. It is situated. You turn towards knowledge, are encircled by knowledge.

Encyclopedias date back to antiquity in the West, at least to the Historia naturalis (AD 77) of Pliny the Elder. The early enterprises down through the Middle Ages sought more than the mere codification of knowledge. The Speculum Majus (1244) of Vincent de Beauvais, for example, tried to show not only how the world is, but how it might be made better. His encyclopedia was divided into three parts entitled Nature, Instruction, and History. Nature was organized according to the order of the six days of creation. But the encyclopedia, as we recognize it today, took shape in the Eighteenth Century and at its origin was the work of one man, the Scottish scholar Ephraim Chambers, who published his prestigious Cyclopaedia in 2 volumes in 1728 . Chambers used a coherent, if incomplete, taxonomy and endeavoured to connect scattered articles by a system of references and to consider 'the several matters, not only in themselves, but relatively, or as they respect each other.' Chambers established a sound bibliographic practice that has been a feature of encyclopedias ever since.

The translation of Chambers's work into French inspired the singular editorial adventure of the Enlightenment, l'Encyclopédie of Diderot and $\mathrm{d}$ 'Alembert, a work that began as a simple translation and ended up as an attempt to incarnate all the power of knowledge, a virtual 'war 
machine' in the battle against ignorance and superstition. L'Encyclopédie was the very definition of the Enlightenment and remains an emblem of French culture.

\section{The Making of L'Encyclopédie}

The first stirrings of l'Encyclopédie occurred in 1745 when the bookseller André-François Le Breton formed a plan to bring out a French translation of Chambers's Cyclopaedia. He engaged the mathematician d'Alembert and the philosopher-writer Denis Diderot, who became joint editors in 1747. Diderot, by temperament a polymath, saw the potential of what Chambers had done. What could be more rewarding, as well as useful, to present the new mass of knowledge and discovery of the great age of French science and letters - the epoch of Descartes, Racine, and Bossuet? What an opportunity for the enemies of prejudice, ignorance and superstition to create a fighting force? Though government and church were deeply suspicious of the enterprise from the start, Diderot's account of the potential of the project even dazzled the old Chancellor of France himself, d'Aguessau.

A year or two later, Diderot drew up a prospectus, in which he showed plans to retain the best part of Chambers. He and d'Alembert then had to decide upon some overall system of classification to serve as both a shaping principle and a means for the retrieval of information. They were influenced here by Buffon's Histoire naturelle, which attempted the almost impossible task of organizing the natural world. For an even vaster scope, the editors needed a 'tree of knowledge.' In the work of Francis Bacon just such a tree existed, based on human faculties; that is, on the sources of knowledge: memory, reason, and imagination. These would correspond to the three great branches of knowledge: History (or, Natural history, for history as we know it was not then a subject for serious study), Philosophy, and Poetry. This system was set out by Diderot in an elaborate 'Illustrated System of Human Knowledge.' The tree differed from Bacon's in treating religion as a mere branch of philosophy.

L'Encyclopédie would serve all the purposes of a library for a professional man on any subject apart from his own. As a totality it should become a 'sanctuary' where 'men's knowledge shall be secure from time and revolutions.' It should be more than a repository but also an engine of research, a stimulus to invention, and it should promote fresh discoveries and 'excite genius to open untrodden paths for itself, treating as their stepping-off place the point where great men have stopped.' 
On the surface, an alphabetical arrangement of entries seems to violate the notion of a 'tree of knowledge' but this deficiency would be overcome by an elaborate system of cross-references, really the first innovation in what today we mundanely call information management. To establish the authority of the text, Diderot would ask the greatest minds of his time to participate. He asked his then friend Rousseau to write on music, Dauberton on natural history and numerous government officials to describe technical matters such as naval tactics, engineering, finance. He asked the composer Cahusac to write on ballet and opera, César du Marsais on grammar. Theology was a trickier matter because of the power of the censors and the anti-religious proclivities of the philosophes. Some of the first entries, such as that by abbé Mallet on 'Arche de Noé,' disguised their true feelings with satire, in this case by ridiculing the discussion about the exact arrangement of the animals on the ark. D'Alembert wrote on mathematics and physics and Diderot on almost everything, including in the first volume 'Arabes,' 'Argent,' and 'Acier.' From his social background Diderot brought his special interest in the Arts (that is, crafts and industry) to l'Encyclopédie, a significant fact since most educated persons of the time considered such matters below their dignity. For Diderot, the son of a cutler, this was considered a matter of justice. He visited workshops, interviewed craftsmen, studied machines and drawings. To help illustrate complex processes, such as steel-making, he commissioned magnificent engravings to accompany the entries.

In 1749 Diderot's book Pensées philosophiques was burned by the public hangman. That year the French government rounded up anti-government propagandists, atheists, and abusers of the King, among them Diderot, who was carried off by a lettre de cachet. He was interned at Vincennes where he suffered greatly from confinement. He offered an abject submission and, after promising to recant, he was released. He resumed work on l'Encyclopédie in November 1749, seeing at once how much editing he had to do on the material that had accumulated. Some of this work was needed to 'improve' the entries by adding, for example, to the entry 'Ame' a subtle ridicule of the whole discussion of the exact location of the soul. Diderot early on faced the challenge of description, realizing the gaps in language and the impossibility of clear explanation of complex processes. On the topic of 'Bas' (manufacture of stockings) he wrote that 'the interdependence of the machine's various parts would seem to require one to talk about them and illustrate them, all at the same time; and that is impossible.' We can only assume that he would have welcomed current technologies of animation and multimedia.

The first volume appeared in June 1751 . On its title page was this epigraph from Horace: 
Tantum series juncturaque pollet/Tantum de medio sumptis accedit honoris! ('What grace may be added to commonplace matters by the power of order and connection.')

D'Alembert's 'Preliminary Discourse' in Volume I explained how the work is to function as an encyclopedia and as a dictionary. As an encyclopedia, the aim was to display human knowledge, not in the order in which it happens, but from the point of view of an eagle, which he called 'encyclopaedic order.' This survey of the vast labyrinth of knowledge 'distinguishes the general branches of human knowledge and points which separate or unite them, and even sometimes glimpses the secret routes which connect them.' His ideas were based on Francis Bacon's 'tree of knowledge' but d'Alembert warned the reader not to expect too much of any system of classification.

The general reader would encounter the work in 'dictionary order' (that is, in alphabetical order by headword). The reader would glimpse the inner order with a system of cross-references that would take him back down the tree of knowledge. Central to this system was d'Alembert's vision of the unity of truth and the rationalist mindset of the Enlightenment in which knowledge is an uninterrupted series or 'great chain' of propositions. As d'Alembert put it: 'The universe, for someone who was able to take it in as a whole, from a single standpoint, would appear as a unitary fact and a single great truth.'

The editors of l'Encyclopédie were very slighting in their attitude towards human history, which was relegated to a small fraction of the Arts of Memory and not regarded as a serious intellectual description. Nor were there biographical entries. The philosophes were determined to focus on ideas and principles and to avoid personal histories, which would only serve to glorify soldiers, bishops and Kings.

Given the power of the censor, there was a need not to give mortal offence. Even the atheist d'Alembert pretended to pay pious tribute to God. The challenge of outwitting the censors gives l'Encyclopédie much of its character: ridiculing pagan rituals and by analogy their Christian counterparts, focussing on the bizarre aspects of religion, using imaginary interlocutors, for example a visitor from China, to raise objections to an article of faith. Diderot's entry 'Adorer' deals in the same breath with the worship of god and the worship of one's mistress. The most underhanded strategy was the sly system of cross-references, which led the reader to entries that would undermine the current article.

When Volume II appeared in 1752, a controversy erupted over the entry 'Certitude' by abbé de Prades, and the King was induced by the Church to ban the first two volumes in exchange for prayers to save his 
mortally ill daughter Henriette. By Volume III the success so far had encouraged other famous lumières, such as Montesquieu, to contribute.

Volume V, which appeared in November 1755, included the entry 'Encyclopédie' by Diderot himself. He argued that this above all was the exact time in human history to undertake such a project, with reason in the ascendance, philosophy advancing, men shaking the yokes of authority and custom. L'Encyclopédie must be more than a repository of simple facts. It must employ numerous contributors, men of letters linked by general interests of mankind, since no one person or group possesses all knowledge. It must draw on the skills of artists as well as scholars.

On the topic of arrangement, Diderot notes that the word 'encyclopédie' itself implies that it begins and ends somewhere, or nowhere. Since the universe can be described from an infinity of different points of view, why then not place Man at the centre of all things and then begin and end with him. The question of what space should be allotted to individual articles he declared unanswerable, since scholars themselves make the most wildly diverse claims as to the scope of their work, a situation that has certainly not changed in our time.

The second question Diderot dealt with was how to distribute material along the branches of topic areas. The encyclopedic order would function globally, with the dictionary arrangement providing local detail and cross-references functioning as 'itineraries' between the two worlds. In an approach clearly philosophical, and not rhetorical, Diderot defined an article as a single argument which starts with an individual phenomenon, ascends to less specific knowledge and then to a broader plane, until one arrives at the knowledge of axioms, 'for in any sphere of knowledge, one has not covered all the ground until one has arrived at a principle which one can neither prove, define, classify obscure or deny without losing part of the daylight already won and taking a step backwards into the shadows.' Diderot boldly criticized his own work as failing on most of the accounts. In this entry, Diderot gives away the devious game he had been playing with the cross-references, giving the work an 'inner force and a secret efficiency.'

Voltaire was an early admirer of l'Encyclopédie. He believed that it could play an important role in transmitting knowledge to posterity. In Volume IV his entries on 'Eloquence,' 'Elegance,' 'Ésprit' and 'Littérature' appeared. These were belles-lettristic entries, and Voltaire forced the editors to face up to the weakness of their work. D'Alembert admitted that it was 'a monument to what we wanted, and were not able to achieve.' He stuck out his neck and asked Voltaire to write an entry on Geneva. Voltaire himself hatched a plan for a Swiss pastor, Polier de Bottens, to write entries espousing Voltaire's own religious views. In 
October 1757 Volume VII appeared with Voltaire's 'Geneva,' a diatribe against Swiss attitudes and the 'atrocious soul' of Calvin. The entry, and d'Alembert's recklessness caused a furore and placed Diderot in a difficult position. On March 8, 1759 l'Encyclopédie was suppressed by royal decree.

Some years later, Voltaire recounted a story that a servant at court had told him. Louis XV was dining at the Petit Trianon when the conversation turned to gunpowder. The Duc de Nivernois declared that it was absurd that people killed partridges or people without having the least understanding of the means they were doing it with. 'Alas it is the same with everything in the world,' replied Mme de Pompadour, who added that she had not the least knowledge of how her stockings were made. 'It is a pity,' said another, 'that your majesty has confiscated our encyclopedias. We would soon have found the answers there.' The King defended the confiscation. He had been told that it was a danger to his regime. He sent three footmen to fetch the volumes, which were an instant success in explaining the formula for gunpowder and in charming Mme de Pompadour with Diderot's account of how her stockings were made. The rest of the party fell on the volumes, said Voltaire, 'like the daughters of Lycomedes on Ulysses' jewels.'

Some time in 1764 Diderot went to the printer to consult his own article on Sarrasins. To his horror he found the entry mutilated. On examination he found many others similarly defaced. The printer, Le Breton, out of cowardice and prudence, had decided to emasculate l'Encyclopédie behind Diderot's back and had destroyed the manuscripts so that the damage could not be repaired.

Of course, the story of Diderot and l'Encyclopédie is inspiring to anyone undertaking a similar project. L'Encyclopédie has taken on a kind of mythical stature, since the theory that the Revolution was more or less the direct work of the philosophes took a long time to die. Reflecting on my own experience, when I became editor-in-chief of The Canadian Encyclopedia in 1980, both the ideas that a work of global knowledge could change the world and that information could be arranged according to a rational system were still alive. Certainly, the public's expectations of what an encyclopedia should be had not changed. In the mind of the general public, if not of the scholarly community, this was a worthy enterprise. 


\section{The Creation of The Canadian Encyclopedia}

The well-known Edmonton publisher and nationalist, Mel Hurtig, had tried to procure funding for a Canadian encyclopedia for many years, without success, until Premier Peter Lougheed took an interest and agreed to fund the research and development as part of the celebrations of Alberta's 75th anniversary as a province.

Whatever its practical uses might be, Hurtig's motives for producing an encyclopedia were not so unlike the motives of the philosophes, for he wanted a work of knowledge that would somehow change the world, that would celebrate accomplishment, that would combat ignorance. By making Canadians more aware of ourselves, it would perhaps preserve us. His argument was buttressed by one of those studies showing how ignorant Canadian students are of their own country that periodically causes such hand-wringing among educators. There had not been an encyclopedia produced in Canada since 1957, and that had been published by the American company, Grolier.

I had had no experience in such an undertaking but soon saw the enormous expectations placed on any encyclopedia. There was, first of all, the idea that it could somehow contribute to nationhood, that it might finally help define the indefinable Canadian identity, that it would confirm that oil-rich Alberta cared about its role in Canada. Secondly, there is the idea buried in that word encyclopedia. But the idea of encompassing a full circle of human knowledge was a dubious ambition, even in Medieval times when Vincent de Beauvais set down his Speculum majus. Was it ever possible to describe every place, every idea, every person, every bird, every flower within the confines of a single printed work? Needless to say, the past 300 or 400 years have added beyond measure to what is known of the universe, of the natural world, of history and prehistory; the number of places in Canada alone probably outnumbers the significant places in Europe in Vincent's time; the number of people has grown exponentially. I emphasize this point because, although most people know the body of human knowledge is immense, many of them still cling to d'Alembert's belief that a unity of knowledge can somehow be contained, if not in an encyclopedia, then perhaps today by the World Wide Web.

There is yet another expectation for an encyclopedia: that it remain a beacon of authority not only in a sea of misinformation but amid the scattered debris left by postmodernist deconstruction. In any event, our encyclopedia has been quoted in the House of Commons Hansard, in more than one Supreme Court Decision, and even by the present premier of Quebec during the controversy over Canada's role in the Quebec Conference during World War Two. The way to establish authority, now 
as in Diderot's day, is to hire experts to write the entries, and we have attracted some 4000 contributors to the task.

What our encyclopedia has helped to reveal, at least to the editors, is that the definition of what we know, or what an expert knows, can be very complex. While an editor of an encyclopedia is expected to know a little about a great many things (Isaiah Berlin's fox), a great many people know one big thing. Over the years some of these people have written to me, pointing out errors of fact or contesting points of interpretation. My favourite letters are from those who write from their direct experience: for example, the man who wrote to tell me that experts who describe the route of the explorer Samuel Hearne have much of it wrong since he himself has taken a canoe and followed that route. I too had my problem with would-be censors, at first in the Alberta government and then from religious groups. I have had religious fundamentalists camped by my office and creationists attempt to discredit me. I was called a communist by the Alberta Report and an anti-business ideologue by the Globe Report on Business. A group of scholars at Laval prepared a secret report on the treatment of Quebec. But it has been in their obsession with place that Canadians have shown their most powerful view of Canada, as many critics across the country scoured the encyclopedia with the sole aim of proving that it was unfair to their locality.

These concerns about the authority of the text take us back to the central creative act of making an encyclopedia, the day-to-day decisions on what topics should be included, what should be left out, and how the isolated topics relate to one another.

In the brief time that I had to plan the encyclopedia, I studied Diderot's Tree of Knowledge and compiled one of my own, though mine owed far more to the practicalities of the Library of Congress List of Subjects than to philosophy. We were, I believe, the first encyclopedia to use a computer in the development of an article list, which considerably quickened revisions and calculations. In order to balance the encyclopedia and to portion out work to the editors, I assigned a preliminary weight to each major subject, the procedure that Diderot had declared impossible to perform rationally. This was of course subjective, but I tried to use an historical method, comparing the weight of subjects in our own lists to those in the 1957 Encyclopedia Canadiana. Canadiana, for example, contained over 100,000 words in biographies of lieutenant-governors, and a mere 15,000 words in biographies of artists. It was easy for me to determine that our encyclopedia would reverse this assessment, and, to the degree that I made those decisions, I was partly laying out a blueprint by which some later encyclopedist would know us. 


\section{Digital Odyssey}

Not only has my work as an editor of The Canadian Encyclopedia been an intellectual challenge, but it has turned out to be, by sheer force of historical co-incidence, a personal Odyssey through a communications revolution. The various print editions have sold over 220,000 sets, in a country where the sale of 15,000 books is considered a bestseller. And then came CD-ROM and the virtual disappearance overnight of the printed encyclopedia. What has the computer wrought?

When I travelled to Columbia University in New York and to Britannica in Chicago in 1980 to study how encyclopedias were made, editors were still using index cards to organize articles, as James Murray had done in his tin shacks during the making of the Oxford English Dictionary 100 years ago. A programmer at the University of Alberta wrote up a database program for The Canadian Encyclopedia that replaced the index cards, kept track of our subject list, article list, word counts, contributors, schedules, costs and much other useful information. I used to wave about printouts from that program to impress visitors with our technical prowess. Now, few of you will be impressed when I tell you that I, personally, on my office computer run a more powerful program and keep track of all that data myself.

While the first step was for the computer to organize and produce the book version of the encyclopedia, the second, more profound change was for the computer to deliver the encyclopedia. The first CD-ROM version of The Canadian Encyclopedia appeared in 1994, with the text and some 300 pictures, one video, a few animal sounds and a rudimentary search engine. The key to CD-ROM was simply its storage capacity of 600 megabytes. Instead of printouts, I now brandished a little silver disk declaring 'look! a whole encyclopedia stored on this little disk.' The structure of the encyclopedia slipped easily into the new format, alphabetical listings, a subject tree and cross references now transformed into hot links. The power that a search engine has over any form of printed index became brilliantly apparent right from the very first version.

Successive technological developments up to our current release have included the following: much more powerful searching ability including natural language queries (asking questions as you might ask in everyday speech); integration of the text of The Canadian Encyclopedia with numerous other reference works, such as an international encyclopedia, two dictionaries, a timeline, a quiz, a thesaurus, bookmarking, and notes that can be added and organized. As regards increased multimedia, there are now about 4000 photos and maps, 100 videos, hundreds of sounds, etc., and we now use the Internet to link entries to web sites and to provide monthly updates. 
The development of this new product grew out of a triple partnership of the publisher as the content provider, the programmers with the database and searching technology, and the interface designers. No-one has been displeased with the results, as there are some 200,000 disks on computers all over Canada. The program itself has evolved and almost taken on a life of its own. None of us knows exactly how the encyclopedia is being used, how people really see it or what it is to become. Our programming developer has moved on to produce a search program that looks for information both on an archive of reference works and out on the Internet, attempting to maintain some semblance of authority in information gathering, ranking responses according to sets of rules. For me, the questions run deeper, all the way back to Diderot.

\section{The Virtual Encyclopedia}

Philosophy was once the master of the great works of knowledge on a universal model. But electronic text ascends at the very moment when philosophy is occupied by its own deconstruction. Does, then, the death of philosophy entail the death of its child, the encyclopedia? Or is an entirely new kind of encyclopedia rising from the ashes?

'The printed book ... seems destined to move to the margin of our literate culture ... the ideal of the book will change: print will no longer define the organization and presentation of knowledge, as it has for the past five centuries.' This comment by Jay David Bolter is of a kind very common these days and it frequently goes hand in hand with declarations of the superior possibilities of electronic text. Electronic text is dynamic, like oral text. Books are static text. Electronic text is a network of ideas. It becomes what Theodor Nelson coined 'hypertext' in the 1960s. Hypertext refers to a form of electronic text, a non-sequential writing that branches and allows choices. At the popular level, it is a series of text chunks (which Roland Barthes calls 'lexia') connected by links. The word 'hypermedia' describes the linking of text to photos, sound, animation, video, virtual reality, etc.

The hypertext revolution itself has roots in the Seventeenth Century through the calculating machines of Pascal, Babbage, and Boole, down to today's machines capable of encoding natural language. Furthermore, l'Encyclopédie's system of cross references foreshadows not only the idea of linking related information but of counter information, of other points of view - a subversiveness appreciated by the browsing generation.

Interestingly, the theoretical basis of hypertext predates the computer, back to a pioneering article by Vannevar Bush in the Atlantic Monthly in 1943 , which called for mechanically linked information retrieval to deal 
with the explosion of information. 'Our ineptitude in getting at the record,' he wrote, 'is largely caused by the artificiality of systems of indexing.' Whether filed by alphabet or subclasses, categories will soon prove inadequate because this is not how the human mind works. It works by association. With one idea in its grasp, the mind snaps to the next that is suggested by an association of thoughts. We need selection by association rather than by indexing in order to retrieve information, to append thoughts, to annotate.

Our own encyclopedia can be used to illustrate the variety of hypertext links available in electronic text, according to George Landow's description:

i) unidirectional, as with a simple link from an entry on John A. Macdonald to Confederation, already present in Diderot's work and easily achieved in print;

ii) bidirectional, as from Mammal to Cougar and back, where we meet the limits of print;

iii) string to lexia, which is more complex as if you were to highlight relevant text in an entry on federalism, click 'related' to run a search of all the contents on the disk and produce a ranked list. This type of search is also very characteristic of the world wide web;

iv) string to string, which brings users to clearly defined points in a preview of the text in order to show immediately the reason for the link and to grasp the relation between portions of the text;

v) one to many, which attaches multiple links to a single anchor, permitting different information from the same textual site;

vi) many to one, with the capacity to click on any word and have it immediately looked up in a dictionary.

Note that some of these links are hard wired by the editors into the text while others are spun out by the program's indexes and still others are chosen by the user.

Thus the involvement of the user in creating associations blurs the boundaries between reader and writer. Readers of our encyclopedia can organize their own lists of entries under their own topic heading, highlight the text that interests them, and annotate with their own text. They can add other documents and share this compilation with others.

On a different level, however, the encyclopedia editor keeps his belief that there can still be some metaphorical unity to knowledge and this one still searches for ways to at least be a guide if not an authority to send users not only to the information that they think they need but also to the information that might astonish, surprise, or please them. To do this, 
Bacon's Tree of Knowledge seems so inadequate in this post-Heisenberg world of uncertainty. I look to other metaphors: galaxies in the place of trees, webs in the place of circles, mosaics in the place of linear text.

\section{The Transformation to a Rhetorical Paideia}

New communications systems create not only increased efficiency and productivity but profound changes in the culture. The mode of information enacts a radical reconfiguration of language. The importance of communications and language has not been properly recognized until recently. Even Marx and Weber, writes Mark Poster, 'were heirs of the $18^{\text {th }}$ century Enlightenment as an intellectual tradition that was profoundly rooted in print culture.' The Enlightenment theory of the 'autonomous, rational individual derived from, and was reinforced by, reading the printed page.' Hegel called reading the newspaper 'the morning prayer of modern man.' Today he would certainly say email.

The spatial materiality of print, with its linear display of sentences and its stability of the word on the page, enables readers to distance themselves. The ideology of the critical individual, reading and thinking in isolation, promotes the authority of the author. Writing is a way of storing language, fixing it so that it can be read. It promotes the transmission of culture. It elevates authors to authorities, fosters critical thinking. Printing is often credited with shaping the autonomous rational individual, a condition of modern democracy. Electronic writing subverts print culture with its volatility, multiple authorship, ease of alteration. Hypertext treats text as a field or network of signs and of the user's own linkages, bringing new associations not associated with the author.

If as Jay David Bolter writes, "The printed book ... seems destined to move to the margin of our literate culture ... the ideal of the book will change: print will no longer define the organization and presentation of knowledge, as it has for the past five centuries,' an editor needs to ask himself, has the encyclopedia survived because of its easy fusion with the new technology or has it sold its enlightened soul? Can it continue to redefine the nature of authority in Derrida's world of multiple meanings and the subversion of the Internet? If we could find a far more complex and subtle system of organization than Bacon's Tree of Knowledge that would redefine what it means to think deeply or critically and find a new metaphor of unity, of the circle of knowledge, would the encyclopedia remain among us as an artifact of Enlightenment, or would this signal the end of the philosophical paideia and the triumph of rhetoric? The challenge an editor faces now is to involve himself in the 
remaking of the text, in the re-interpretation of authority, and not to allow the technocrats, or for that matter deconstructing academics, to dictate how we see the world from d'Alembert's eagle's view, though we acknowledge that we can no longer aspire to first principles or a single great truth. What a goal it would be to give new meaning in the electronic world to that epigraph on l'Encyclopédie, 'What grace may be added to commonplace matters by the power of order and connection.'

\section{JAMES H. MARSH}

Editor in chief, The Canadian Encyclopedia, Edmonton

\section{Bibliography}

Bolter, Jay David, Writing Space: The Computer, Hypertext and the History of Writing (Hillsdale, N.J.: Erlbaum, 1991). Pages 207-08.

Furbank, P. N., Diderot: A Critical Biography (London: Secker \& Warburg, 1993).

Landow, George P., Hypertext 2.0 : The Convergence of Contemporary Critical Theory and Technology (Baltimore: Johns Hopkins UP, 1997).

Poster, Mark, The Second Media Age (Cambridge: Polity Press, 1995).

Schaer, Roland (ed.), Tous les savoirs du monde: Encyclopédies et bibliothèques, de Sumer au $x x i^{\mathrm{e}}$ siècle (Paris: Bibliothèque nationale de France/Flammarion, 1996). 